\title{
Denke as krisisterrein in die verskynsel van kerkkrimping by tradisioneel Afrikaanssprekende susterkerke
}

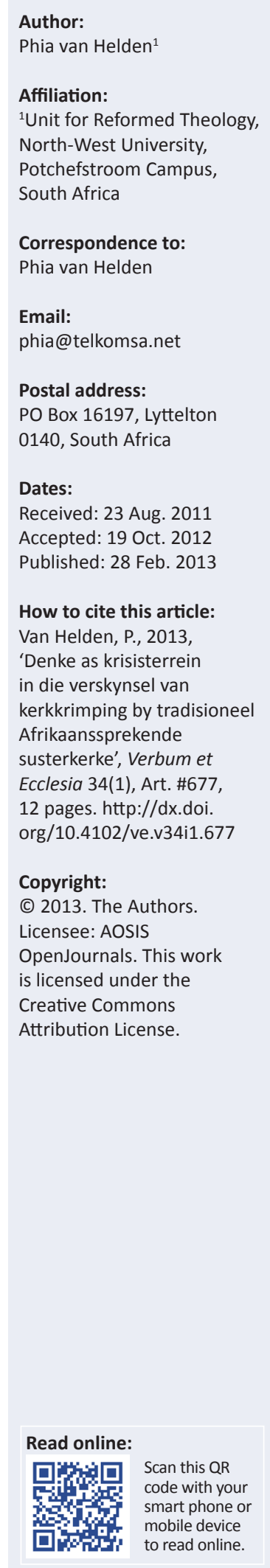

Thinking as a crisis area in the phenomenon of the declining traditionally Afrikaans 'sister churches'. Since little can be done, humanly speaking, to address the numerous factors influencing the decline of churches, it is obvious that everything humanly possible must be done. Thinking plays a major role in ecclesiology. This article focuses on human thinking as crisis area and as variable in ecclesiology. Because thinking is the determining factor controlling human activities, it is necessary to transform and change thinking when imbalances appear under the microscope of the last command of Jesus. Through the Great Commission, the Christocentric paradigm is revealed which serves as a corrective guideline for the imbalances created by the institutionalistic (I-paradigm) or the spiritualistic (S-paradigm) paradigms. Appreciative Inquiry (AI) is rediscovered as Scripture-based approach regarding change in thinking and the resulting change in the ecclesiastic crisis area, thus focussing on a more complete obedience to the Great Commission and promoting the possibility of natural church growth.

\section{Inleiding}

Die kwynende lidmaatgetalle in die tradisioneel gereformeerde kerke word deur talle eksterne en interne faktore op verweefde en komplekse wyse beïnvloed (De Klerk \& Van Helden 2011:1-10). De Klerk en Van Helden behandel breedvoerig die faktore wat aanleiding gee tot die verskynsel van kerkkrimping, gesien teen die Groot Opdrag (Matt 28:18-20; Hand 1:8). Talle van hierdie faktore is buite menslike beheer. Die onmag van die mens in dié konteks het aanleiding gegee tot hierdie artikel, wat aandag skenk aan die een ekklesiologiese faktor wat wél deur die mens aangewend kan word om die kerkpraktyk te wysig. Hierdie faktor is denke as oorsaak van menslike dade (Olivier 2006:141).

Buitelandse navorsers soos Gill (2003:2, 3, 17), Reeder (2012), Runia (1988), Schwarz (1999) en Walls (2002:45-235), maar ook Suid-Afrikaanse navorsers, het hulle uitgespreek oor denke as menslike faktor binne die kerkpraktyk, veral waar uitbreiding nie voorkom nie (Dreyer 2009; Hendriks 1996:142-144; Niemandt 2007:67, 81).

Die huidige dalende getalle in die tradisioneel gereformeerde stroom spruit uit 'n denkparadigma wat oor dekades heen sodanig deur denkstrome en lewensomstandighede (De Klerk \& Van Helden 2011) beïnvloed is dat die Groot Opdrag nie as kern of norm hoog geag of daadwerklik uitgeleef word nie. Omdat die kerke hoofsaaklik op introverte wyse op opbou gefokus het, het hulle denke en handelinge gaandeweg vereng en op die lang duur 'n gevestigde en Skriftuurlik onvolledige denkpatroon laat ontwikkel. Schalekamp (2005b:4) beskryf dié denkpatroon as 'n 'skeefgetrekte ekklesiologie'. Gereformeerdes was skynbaar nie bewus daarvan dat hulle manier van dink en doen rondom die Groot Opdrag onvolledig was nie, anders sou 'n missionêre bedieningsaanslag (uitbou) as hoë prioriteit, gelyk aan opbou, bedink en deurgevoer gewees het. Die volgehoue onvolledige denk- en doenpatroon het vanselfsprekend in 'n ongesonde kerkpraktyk oorgegaan. In die susterkerke is dié ongesondheid só aktueel, dat gereformeerde teoloë dit as 'n krisissituasie bestempel (De Wet 2000:2-7, 107; Dreyer 2009; Hendriks 1996:142, 14; Niemandt 2007:12, 18; Van Rooy 2006:22).

Gehoorsaamheid aan die Groot Opdrag met uitbou as hoë prioriteit was in die bestaansdekades van die 'susterskerke' skynbaar net in beperkte mate en teoreties deel van die kerkpraktyk. 'Onmag' en 'magteloosheid' as gevolg van 'omstandighede' in die lewenspraktyk het prinsipiële denke en dade telkens oorskadu, aldus Van Rooy (2006:22).

Word die Groot Opdrag geëksegetiseer, is dit duidelik dat 'n verbondsverhouding tussen God en die mens direk en duidelik in die Groot Opdrag ingebed is (Bosch 1991:18; Strong 
2007:107-109). Die Groot Opdrag aan die mens toon die bipolariteit van die verbondsverhouding deur die gebruik van die indikatief en die imperatief van die teksdele. Enersyds dui die indikatief op die magsaankondiging (Matt 28:18) en vaste belofte van bystand deur God (Matt 28:20b). Andersyds toon die imperatief die aktiwiteit van die mens aan (Matt 18:19, 20a). Die indikatief omvou die imperatief struktureel en toon en bevestig God se aktiwiteit binne die opdrag. Die imperatief bestaan uit maak dissipels, en dit gebeur deur te gaan (uitbou) en te doop en te leer en / of onderrig (opbou). Dit gee die sleutel tot ' $\mathrm{n}$ gesonde en gebalanseerde kerkpraktyk aan die mens; die sleutel wat werksaam is binne 'n eenheidsisteem van opbou en uitbou (Burger 1999:88, 111, 149, 150; Schalekamp 2005b:31, 34; Van der Merwe 2006:15, 16; Van Helden 2010:48). Die eenheidsisteem moet egter deur die mens bedink word en vereis derhalwe Christosentriese (verbonds)denke. Navorsing wat oor die afgelope drie dekades wêreldwyd deur Schwarz (1999) gedoen is, en steeds vanuit die Instituut vir Natuurlike Gemeente-ontwikkeling en kerkgroei in Duitsland gedoen word, toon dat die eenheidsisteem, gerig deur Christosentriese denke, gesonde gemeentes vestig wat mettertyd kwantitatief en kwalitatief groei.

Die susterkerke dink en doen nog grootliks na binne (opbou). Dit word bevestig deur navorsing deur Burger (1999:68, 69) en Niemandt (2007) (NG Kerk), tesame met 'n empiriese ondersoek na die huidige stand van die Nederduitsch Hervormde Kerk deur Dreyer (2009) (NH Kerk), asook 'n steekproef onder sommige GKSA-gemeentes om die denke van lidmate oor die kerkpraktyk te bepaal (Van Helden 2010:297-351; 2013). Die steekproef het Schwarz (2000; Schwarz \& Schalk 1998) se agt kenmerke van kerkgroei (spiritualiteit, bediening, eredienste, groepe, evangelisasie, strukture, leierskap en verhoudings) gebruik om te bepaal tot watter mate die eenheidsisteem tans binne die kerkpraktyk funksioneer, en wat kerkkrimping in die hand werk. Die bevinding was dat daar hoofsaaklik op opbou deur middel van statiese (organisatoriese) aspekte in die kerkpraktyk gefokus word. 'n Denkwyse en handelinge wat sodanige tekens vertoon, ontwikkel in 'n status quo-denk-en-doenleefwyse en word beskryf as institusionalisties (I-denkwyse). Die charismatiese stroom se denke en dade fokus op sy beurt hoofsaaklik op die dinamiese (organiese) aspekte (Gilbert $\&$ Brock 1985) en word hiervolgens as die spiritualistiese denkwyse (S-denkwyse) beskryf.

In hierdie artikel word gefokus op tekens van die I-denkparadigma binne die susterkerke en die omvang van die heersende krisissituasie in die lig van die Groot Opdrag. Voorbereidende stappe vir'n moontlike omkeer word saaklik bespreek aan die hand van 'n denkveranderingsproses, versterk deur die Skriftuurlike instrument, Waarderende Ondersoek (WO).

\section{Krisissituasie \\ Tekens van 'n I-denkparadigma}

Binne 'n denkparadigma is daar altyd twee pole, naamlik die dinamiese (organiese) en die statiese (organisatoriese) pole.
Balans tussen én ter wille van die twee pole kan gevind word en 'n gesonde denkterrein daarstel (Brouwer et al. 2007:176; Schwarz 1999:20, 21). Daar kan egter ook 'n wanbalans (verwoord as onvolledigheid, skeefgetrektheid, mankheid, ongebalanseerdheid) ontwikkel, wat 'n ongesonde kerkpraktyk tot gevolg het (Schwarz ibid:14-48).

Wanneer die kerk as lewende organisme (Ef 4, Rom 12, 1 Kor 12) deur die afwesigheid van een van dié pole gestrem word, ontwikkel 'n ekklesiologiese ongesondheid (Olivier 2006:99; Schalekamp 2005b:4). Wanneer die statiese pool in denke domineer, ontstaan 'n ongesonde toestand, omdat die dinamiese pool grootliks afwesig is (Brouwer et al. 2007:176; Schwarz 1999:20, 21). Daar is sterk tekens dat die statiese pool in die tradisionele stroom oorheers, terwyl die dinamiese aspekte sterk by die charismatiese stroom geld. Wanneer balans egter bedink en gedoen word, ontwikkel daar mettertyd 'n gesonder kerkpraktyk.

In die gereformeerde kerke is Sola Scriptura, die suiwer Woordnavolging en die dogma daarvan, 'n uitermate sterk punt (Kruger 2012; Smit 2011). Schwarz se navorsing het getoon dat denke en dade wat só gefokus is op die Skrif (statiese aspek), gewoonlik aan die dinamiese pool van belewing ontbreek. Terselfdertyd speel rasionalisme en formalisme onder andere 'n beduidende rol (Schwarz 1999). Dié tekens is opmerklik in die susterkerke. Navorsing oor, tekens van I-denke is uitgevoer deur Dreyer (NH Kerk), Van Helden (GKSA), wat dieselfde agt kenmerke van Schwarz gebruik, asook deur 'n ondersoek van die Departement Sosiologie aan die Hugenotekollege op Wellington (NG Kerk). Laasgenoemde ondersoek het bevind dat lidmate nie 'n behoefte het aan teologiese kwessies en dogma (staties) nie, maar wel aan 'direkte godsdienstige belewing' (dinamies) (Du Toit et al. 2002:26).

Wanneer die klem op statiese aspekte val, word skeefgetrektheid die aanvaarde praktyk. Terselfdertyd bied die organisatoriese krag (statiese aspekte) sekerhede wat mettertyd tot gearriveerdheid in die kerk lei, en uiteraard gekoester word. Niemandt (2007:44) beskryf dié denke en dade as 'n 'instandhoudingsmodel' - 'n tiperende kenmerk van instusionalisme. Dreyer (2009:27) verwys na Kuyper se stelling dat indien die kerk as organisme nie gebalanseerd funksioneer nie (Ef 4, Rom 12, 1 Kor 12), duidelike tekens van institusionalisme sal manifesteer. Dit ondermyn die eenheidsisteem van opbou en uitbou en laat mettertyd 'n krisissituasie ontwikkel wat die terminale tekens van introversie en afwesigheid van uitbreiding of uitbou vertoon - tekens wat sterk in die susterkerke manifesteer.

\section{Manifestasies}

Institusionalisme manifesteer op verskillende wyses, derhalwe word die tekens daarvan ter wille van hierdie artikel slegs kortliks bespreek. Institusionalisme behels onder andere die daarstel van 'n ongeskrewe formule waarvolgens die godsdienstige praktyk dan outomaties funksioneer. Hiérdie verskynsel spruit uit die menslike soeke 
na sekerheid. In dié soeke word organisasie van die kerkpraktyk (staties) en die kerk as organisme (dinamies) nie altyd van mekaar onderskei nie. Die fout wat dan insluip, is dat die balanserende invloed van die statiese organisering van die instansie nie met die dinamiese, organiese kant van die kerk in berekening gebring word nie. Van Helden se steekproef in sommige gemeentes (2010) het hierdie verskynsel grootliks bevestig. Die susterkerke wat tradisie en die 'institusionele gevangenskap' (Jones 2008:13) bo gehoorsaamheid aan die Groot Opdrag stel, is spekend van die institusionele teken bekend as objektivisme (Burger 1999:91, 92, 278; Schwarz 1999:24-32, 42, 191-194; Hendriks 2003; Olivier 2006:80, $128,129)$.

Uit die soeke na sekerheid (staties) word ortodokse gesag soms aan die Woord toegesê en die lewende verhouding van die mens tot die Woord word sodoende ondermyn. Deur die gesag van die Woord word geloof dan outomaties veronderstel (Schwarz 1999:27). Dié tipe institusionele teken staan bekend as heteronomisme en gaan hand aan hand met rasionalisme en vermyding of verwerping van godsdienstige belewing. Die suiwer verkondiging, die dogmatiese en teologiese skat en die 'goud' van die gereformeerde tradisie as statiese pool word in die susterkerk-kringe as die tradisionele stroom se sterk punt gereken (Burger 1999:116; Van Rooy 2006:22; Van Rooy 2007b:32). Daadwerklike belewing van die dinamiese pool (as balansgewend ter wille van 'n gesonde kerkpraktyk) is egter grootliks afwesig. 'n Kerkpraktyk wat hierdie denkpatroon toon, is tiperend van die I-denkparadigma.

Susterkerk-teoloëhet opvallende tekens van institusionalisme binne die susterkerke veral gedurende die afgelope twee dekades as krisisgegewens geïdentifiseer en onder die aandag van kerklui probeer bring.

\section{Krisisterrein \\ 'n Denkkrisis}

Dit is vanselfsprekend dat enige praktyk nie vanself, buite die mens om, ontstaan nie. Die kerkpraktyk is ook die direkte gevolg van menslike denke. Die krimpende gereformeerde kerkpraktyk is die terrein waar die krisissituasie hom afspeel. Die krisisterrein weerspieël 'n 'oorlewingstryd' (Van Rooy 2006:22) deur die handhawing van die 'instandhoudingsmodel' (Niemandt 2007:44). Jones (2008:13) beskryf dié krisisterrein as 'institusionele gevangenisskap'. Ander susterkerk-teoloë, soos Burger (1999:278), De Wet (2000:2), Dreyer (2009), Lotter en Thompson (2005:695714), Malan (2004), Niemandt (ibid:32, 37-49), Olivier (2006:84) en Van Rooy (2007a:39), voer aan dat formalisme, onaanpasbaarheid, selfsug en magsug, fundamentalisme of rigiditeit, dogmatisme, wettisisme, tradisionalisme, gearriveerdheid of introversie, en gebrek aan Godskennis die huidige krisissituasie beskryf.

Word dié denkparadigma gemeet aan die Groot Opdrag, sien ons dat dit waarlik 'n krisis is. Die Groot Opdrag beveel opbou en uitbou as eenheidsisteem, soos gestel deur Jesus Christus.
Christosentriese denke vertoon dus in elke aspek van opbou en uitbou ' $n$ balans tussen dinamiese en statiese aspekte. Dié Christosentriese sisteem voorkom derhalwe onvolledige of skeefgetrekte denke. Wat die krisis intensiveer, is die feit dat gereformeerdes skynbaar grootliks oningelig, onbewus en onwetend is oor hierdie ekklesiologiese toestand.

Dié toestand staan as hindernis in die pad van insig, bekering, verandering, verbetering, reformasie en groei. Burger (1999:8) het hierdie denkmanifestasies verwoord as 'n enorme denkkrisis (Niemandt 2007:62-163; Roxburgh 1997:26, 27; Tickle 2008:150-160).

\section{Denkkrisis as krisisskrif aan die muur}

Die skynbare afwesigheid van kennis van die ware toedrag van die kerktoestand, maar ook ontkenning daarvan en die skynbare onvermoë om die introverte kerkpraktyk proaktief by kultuurverandering aan te pas (Du Toit et al. 2002:49), spreek van die denkkrisis wat in die susterkerke heers. Niemandt (2007) gebruik sinsnedes soos 'gedagte agter die begrip' (bl. 65), 'n ganse nuwe manier van lewe', 'nuwe vrae' wat 'bedink' moet word (ibid:69, 77, 83) ter verduideliking van die toestand. Taalgebruik soos dié van Niemandt en ander teoloë na wie in hierdie artikel verwys word, dui aan dat denke moet omkeer, ánders gerig moet word met die volle fokus op Jesus. Bosch (1991:2) haal Kraemer aan, wat aangevoer het dat wanneer daar jaar na jaar in skynbare onoplettendheid bloot met 'n gevestigde jaarprogram in die kerkpraktyk voortgegaan word, heers daar in werklikheid reeds 'n intense krisistoestand. Dié toestand dui die krisisskrif aan die muur aan; 'n krisis wat al hoe opvallender word en waaroor steeds geskryf word ter wille van bewusmaking en om die denke van gereformeerdes tot omkeer te bring.

Die erns van die krisisskrif lei tot die stel van krisisvrae: Weet gelowiges wat die Groot Opdrag beveel? Word God se teenwoordigheid werklik beleef? Word die bediening ter wille van die evangelie ingespan? Wil gelowiges werklik kerk wees? Word gemeentebou (opbou of uitbou) werklik nagestreef? Is die nastrewing werklik sonder voorwaardes, soos byvoorbeeld die invloed van die kleur- of taalgrens? (Burger 1999:16, 136; Niemandt 2007:147-163; Van der Merwe 2009a, 2009b; Van Helden 2010:297-350; 2013; Venter 2009).

By besinning oor hierdie vrae, het sommige teoloë reeds gekom tot die besef van die ekklesiologiese verwaarlosing, of soos dit in Die Kerkblad (2007:41) verwoord is: die 'platval van die 'susterkerklike koek' (vgl. Burger 1999:8; De Wet 2000:2-4; Du Toit 2008:1; Hendriks 1996:144; Oliver 2007: 23-40; Van Rooy 2007a:39-41). Die NH-teoloog Van der Merwe (2009b) stel dit soos volg: "n ernstige krisis wat van ons niks minder as 'n kerkhervorming vra nie, verskeie navorsers praat selfs van 'n radikale kerkhervorming' (vgl. Dreyer 2009). In bykans elke artikel van Hendriks (1993, 1996, $1999,2003)$ word die toestand geskets as 'n status quo-situasie, oordrewe tradisie, geloofstraagheid en wat moontlik die dieptepunt van die krisis is, naamlik gebrek aan Godskennis. 'n Ondersoek onder sommige GKSA-gemeentes het tot soortgelyke bevindings gelei (Van Helden 2010:297-350). Dit 
is opvallend dat Van der Merwe, Hendriks en Van Helden tot dieselfde gevolgtrekking kom, naamlik dat I-denke die (krisis)praktyk bepaal.

\section{Onvoorbereide krisisterrein}

God se bevel (Groot Opdrag) aan die mens is om te groei en uit te brei. As die Groot Opdrag veronagsaam word, sal groei en uitbreiding eenvoudig nie plaasvind nie. Eerlik beskou is die afwesigheid van uitbreiding bloot 'n natuurlike gevolg van 'n menslik-verwaarloosde kerkpraktyk wat die Gees bedroef (vgl. Walls 2002:274).

Die krisis is sodanig dat gereformeerdes se sterk punt, Sola Scriptura (Kruger 2012; Smit 2011), hom in werklikheid nié so suiwer openbaar as wat gedink of aanvaar word nie. Dit beteken dat die Skrif nie volledig in denke en dade gehoorsaam word nie. Sou Sola Scriptura volledig gevolg word, sou introversie nie ontwikkel nie, en sou evangelisasie en sending sáám met opbou hoë prioriteit in gemeentes gekry het. Die situasie roep om dringende kennisname, ernstige ondersoek en/of toetsing en 'n diepgaande omkeer en verandering (Du Toit et al. 2002:49; Dreyer 2009; Jones 2008:13; Meylahn 2011; Niemandt 2007; Van der Merwe 2009b; Van Helden 2010:351; Hendriks 1993, 1996, 1999, 2003; vgl. Tickle 2008:13-17).

\section{Herskeppingsmoontlikhede}

Walls (2002:46) beskryf só 'n krisistendens as 'n oxygenstarved-krisisbestel. Dit is dus noodsaaklik om die 'suurstoftekort' aan te vul. Almal betrokke in die krisisbestel behoort optimaal bewus gemaak te word van die toestand, sodat effektiewe herskeppingsmoontlikhede 'vars lug' in die bedompige grafkelder kan laat instroom (Meylahn 2011; Niemandt 2007:15, 44). Soos Van der Merwe (2009b) dit stel: 'radikale kerkhervorming' moet plaasvind.

Die teologiese wetenskap doen 'n beroep spesifiek op Afrikateoloë (wat susterkerk-teoloë insluit) om die implikasie van die Groot Opdrag met geloofswaagmoed, vernuwend op alle terreine van die kerkpraktyk, en as roeping regstellend aan te spreek en aan te pak (Burger 1995:34; Niemandt 2007:50, 53; 2007:147-151; Reeder 2012; Smit \& Vorster 2000:530; Van der Merwe 2009a; Walls 2002:112, 113, 277). Dié vernuwende [revitalising] denkingesteldheid (Reeder ibid) kan ook leiding bied in die identiteitskrisis wat die tradisioneel ontwikkelde wêreldgeoriënteerde Afrikaner, sowel as die Suid-Afrikaanse Afrosentriese mens, in die huidige oorgangstydperk beleef (Bosch 1991:57-59; De Wet 2000:2, 21; Meylahn 2011; Van der Merwe 2011).

\section{Identiteitskrisis en herstruktureringskrisis}

In dié situasie is dit belangrik om te besef dat SuidAfrikaners ' $n$ identiteitskrisis beleef, en dat die huidige sosiale oorgangsproses onkeerbaar is en verdere verandering meebring (Dreyer 2009; Kirkpatrick 2011; Meylahn 2011; Smit 2011; Van der Merwe 2011; Van Helden 2010:239). Alhoewel geskiedenis, gebruike, blyplek en 'n gevoel van saamhorigheid in die verlede grootliks tussen bevolkingsgroepe in Suid-Afrika verskil het, is dit duidelik dat een saak gedeel word, naamlik 'n identiteitskrisis (Meylahn ibid; Tickle 2008:33). Die Afrosentriese mens in Suid-Afrika ervaar dieselfde herstruktureringskrisis as die ontwikkelde, wêreldgeoriënteerde mens. Dit kom neer op die soeke na identiteit te midde van beïnvloedende denkstrome en voortdurende landsveranderinge.

Verder kan die twee godsdiensstrome (tradisioneel en charismaties) se swakhede en ongebalanseerdhede die identiteitskrisis versterk en die herstruktureringsproses benadeel. Die Afro-Christelikheid, wat oorwegend die S-denkparadigma vertoon, kan mettertyd tot grootskaalse verskuiwings lei, aangesien die charismatiese benadering uitgedien kan raak en die meeste van sy aanhangers dan bloot oorgaan tot die heidendom (Du Toit et al. 2002:26; Hendriks 1993:545; Fellows 2007). Aan die ander kant is die tradisionele stroom só vasgevang in 'n introverte, dalende kurwe (Dreyer 2009:6; Hendriks ibid:548, 550:549, 1996:143; Niemandt 2007:37; Van der Merwe 2009b; Van Helden 2010:178; Tickle 2008:143) dat die Skrif skynbaar nie as roepinggewende en identiteitgewende geloofskragbron binne die huidige gesekulariseerde wêreld herken word nie.

Geskiedeniskrisis, geloofskrisis en sekularisme: Die geskiedenis van die tradisionele Afrikaanssprekende Suid-Afrikaner getuig van twee uiterstes, naamlik ondergang en oorlewing (Giliomee 2004:xv, xvi, 419). In die verlede het dit gemanifesteer deur 'n ondergangsfase gevolg deur 'n lewenskragtige oorlewingsfase. Voorbeelde is die Vryheidsoorlog (ondergangsfase) en die Afrikanernasionalisme en regeringstydperk (oorlewingsfase) van 1948 tot 1994. Die oorlewingsywer van die Afrikaner het sedert 1994 'n geweldige knou gekry, hoofsaaklik omdat sy politieke mag afgeneem het (Du Toit et al. 2002:45; Oliver 2007:32). Afrikaans, as die draer van 'n eens verenigde identiteit, is ook direk geraak. Die denke van die Afrikaner is ten diepste in 'n geloofsskrisis gedompel, aangesien die skynbare dryfveer om as 'geroepenes' (Giliomee 2004:611, $619,622-626,630)$ in diens van die evangelie in Suid-Afrika te leef, verswak het.

In die herstruktureringsproses maak godsdiens altyd deel uit van die maatskaplike konstruk [social construct] (Tickle 2008:33). Die identiteits-, geskiedenis- en geloofskrisis veroorsaak dat herstrukturering tot voordeel van 'n Afrikadienswilligheid nie maklik plaasvind nie. Hierdie 'agtergeblewenheid' word versterk deurdat die Afrikaner nie werklik bewustelik kennis neem van die enorm veranderde en aangepaste taak of roeping in die land nie. Boonop word 'n oproep tot gewilligheid daartoe nie graag gehoor nie (Burger 1995:9; Van der Merwe 2009b). Die Groot Opdrag word derhalwe, as gevolg van die verweefde krisisse, verder vermy.

Die sekuralisasieproses omvou die krisisse; die denkwyse van die Afrikaner is grootliks daardeur beïnvloed (Du Toit et al. 2000:58; De Wet 2000:1, 2; Hendriks 1996:142, 143). Voor die intense sosiale verandering ingetree het, is 
geestelike groei skynbaar nie werklik deur die gelowige nagejaag nie. Gevolglik, toe sosiale veranderinge begin intree, is die (yl)gelowiges grootliks ontnugter (Giliomee 2004:5; Hendriks 2000:80). Ontnugtering gee aanleiding tot 'n geloofskrisis waar geloof en die geloofwaardigheid van die kerk onder verdenking kom, kerkgang onbelangrik word en geloofsinstansies negatief geraak word. Onkerklikheid, buitekerklikheid en verwêreldliking of sekularisasie neem derhalwe grootskaals toe en vererger die bestaande krisisse (Cameron et al. 2005:55; Gill 2003:2, 3, 153; Hendriks 2000:1-5; Heitink 1979:334; Heitink 1999:43; Louw 2012; Van Wyk 2006:5-7).

Konserwatisme en die oorlewingstryd: Denke as remmende faktor in die herstruktureringsproses word weerspieël deur 'n geneigdheid om laer te trek, 'verknog' te wees aan die 'ou wêreld' (Niemandt 2007:37, 39, 44) en om op oordrewe wyse aan gevestigde gewoontes en sekerhede vas te hou. Dis sprekend van konserwatisme as uitvloeisel van die I-denkkrisis (vgl. Hendriks 1996:143). Hofmeyr en Pillay (1994:119) verduidelik konserwatisme as dit wat beoefen en behou word ter wille van die menslike sekerheid wat daaruit geput word. Algemeen gesproke is konserwatiewe denke wat gerig is op behoud en opbou nie noodwendig 'n negatiewe faktor nie. Daarenteen bewerk oordrewe konserwatiewe ingekeerdheid en ongebalanseerdhede, veral waar gelowiges eerlik waar nie bewus is van die invloede van die oorgangstyd nie, en ook nie besef (Niemandt 2007:14, 15) wat die eise van die huidige versplinterde samelewing (Du Toit et al. 2000:167; Hendriks 1999:18; Walls 2002:21-23) en sneltoenemende heidendom behels nie (vgl. Fellows 2007).

Ter verswaring van die krisisse word gereeld van onversoenbaarhede, selfs kerkskeuring, gehoor; dít, in teenstelling met die gereformeerde belydenis waar eenheid nagestreef behoort te word (Nederlandse Geloofsbelydenis 29). Waar denkherstrukturering plaasvind, is onderlinge verdeling allerweë ter sprake. Groepvorming vind dan plaas by diegene wat meer behoudend of konserwatief dink, asook by diegene wat meer vry of liberaal dink (vgl. Tickle 2008:58). Die najaag van skeuring as 'n krisispraktyk op sigself kom grootliks neer op ononderhandelbare verheerliking van eie insigte (denke), projektering van menslike wanhoop en vrees (denke), asook 'n skynbare onbereidwilligheid of onvermoë om te hervorm (denke) (Botha 2006:22; Hendriks 2003). Hendriks (1996:143) verwoord sodanige denke as "n afwaartse spiraal van agteruitgang' wat 'verlamming' bewerkstellig.

Dit is duidelik dat die gevestigde denke 'n skynbaar onverskuifbare kerkpraktyk gevestig het. Dreyer (2009:7) se studie voer aan dat I-denke die oorsaak is van geblokkeerde denkwyses. Die steekproef wat in sommige GKSAgemeentes gedoen is, bevestig ook die oorwig van I-denke (Van Helden 2010:294-351). Nelus Niemandt, moderator van die NG Kerk se algemene sinodes, bevestig dat denke in hoofstroomkerke 'nie juis bedag (is) op wat aan die gang is nie' (Niemandt 2007:15), dat kerke vasgevang is in introversie (ibid:44), dat die missionêre roeping op die agtergrond staan en dat 'n akute leierskapskrisis in die kwynende kerke bestaan (Louw 2012; Van der Merwe 2009a; vgl. Schwarz 1999:27, 187, 188; Reeder 2008).

Vanaf veral 1990 het getalle in die susterkerke konstant afgeneem (De Bruyn 1989; Dreyer 1990; Gaum 1990, 2000; Hendriks 1993, 2000; Schalekamp 2005a; Storm 2005). Kommer daaroor is aanvanklik sporadies verwoord, maar rondom die eeuwisseling het die susterkerke ernstiger daaroor begin besin (Du Toit et al. 2002; Gaum 1990:v; Hendriks 1996:142; Pretorius 2006:17; Smit \& Vorster 2000:527; Van Rooy 2006:22).

Tabel 1 is ' $n$ vergelyking van lidmaatgetalle in die onderskeie susterkerke soos aangedui in die almanakke en jaarboeke oor die laaste dekade van die twintigste eeu.

Ten spyte van besinning, het getalle bly daal. Tabel 2 toon die getalle-afname tussen 2000 en 2005 soos aangegee in die susterkerke se kerkalmanakke en jaarboeke.

Die statistieke in dié twee tabelle toon slegs die oortjies van die 'susterkerk-seekoei'. Daarmee word bedoel dat die grootste deel van die krisissituasie 'onsigbaar' is en dat daar derhalwe weinig kennis, insig of besef (denke)

TABEL 1: Getalle-afname in die susterkerke oor die laaste dekade van die twintigste eeu.

\begin{tabular}{lccc}
\hline Lidmate & \multicolumn{3}{c}{ Kerkgenootskap } \\
\cline { 2 - 4 } & NG & NH & GKSA \\
\hline $\mathbf{1 9 9 0}$ & 958736 & 131697 & 78629 \\
Belydendes & 25024 & 4363 & 2184 \\
Gedoop & & & \\
$\mathbf{2 0 0 0}$ & 918790 & 120937 & 74952 \\
Belydendes & 16135 & 1958 & 1282 \\
Gedoop & & & \\
Persentasie afname in dekade & 4.2 & 8.2 & 4.7 \\
Belydendes & 35.5 & 55.1 & 41.3 \\
Gedoop & &
\end{tabular}

Bronne: NG: Gaum, F., 1990, Jaarboek van die Nederduitse Gereformeerde Kerke, Jaargang 141, Nasionale Boekdrukkery, Kaap; Gaum, F., 2000, Jaarboek van die Nederduitse Gereformeerde Kerke, Jaargang 151, Tydskriftemaatskappy van die NG Kerk, Tygervallei; NH: Dreyer, P.S., 1990, Almanak, Jaargang 84, Gutenberg, Pretoria-Wes; Storm, J.G.M., 2001, Almanak, Jaargang 95, SENTEK; GKSA: De Bruyn, F.R.P. (e.a.), 1989, Almanak van die Gereformeerde Kerke in Suid-Afrika, Jaargang 115, Potchefstroom Herald, Potchefstroom; Van der Walt, S.J. (e.a.), 2000, Almanak van die Gereformeerde Kerke in Suid-Afrika, Jaargang 126, United Litho, Potchefstroom

NG, Nederduits Gereformeerd; NH, Nederduits Hervormd; GSKA, Gereformeerde Kerk in Suid-Afrika.

TABEL 2: Getalle-afname in die susterkerke 2000-2005.

\begin{tabular}{lccc}
\hline Lidmate & \multicolumn{3}{c}{ Kerkgenootskap } \\
\cline { 2 - 4 } & NG & NH & GKSA \\
\hline $\mathbf{2 0 0 5}$ & 894429 & 112756 & 70660 \\
Belydend & & & \\
$\mathbf{2 0 0 7}$ & 889777 & 111799 & 70225 \\
Belydend & 0.5 & 0.9 & 0.6 \\
Persentasie afname & & & \\
\hline
\end{tabular}

Bronne: NG: Symington, J., 2005, Jaarboek van die Nederduitse Gereformeerde Kerke, Jaargang 156, Tydskriftemaatskappy van die NG Kerk, Wellington; Symington, J., 2007, Jaarboek van die Nederduitse Gereformeerde Kerke, Jaargang 158, Tydskrifmaatskappy van die NG Kerk, Wellington; NH: Storm, J.G.M., 2005, Almanak, Jaargang 99, SENTEK; Beukes, A.P.J., 2007, Almanak, Jaargang 101, SENTEK; GKSA: Schalekamp, M.E., 2005c, Alman die
Gereformeerde Kerk in Suid-Afrika, Potchefstroom; Vogel, W. (e.a.)., 2007, Almanak van die Gereformeede Kerke in Suid-Afrika, Jaargang 133, V \& R Drukkery (Edms.) Bpk., Pretoria
Gerat NG, Nederduits Gereformeerd; NH, Nederduits Hervormd; GSKA, Gereformeerde Kerk in Suid-Afrika. 
daaroor bestaan (vgl. Brouwer et al. 2007:16-20, 105; Saarinen 1992:1-23). Die broodnodige denkverandering begin doodeenvoudig nie voluit nie, aangesien daar skynbaar 'n enorme mate van oningeligtheid, onwetendheid en onkunde oor die krisissituasie heers.

\section{Oningeligtheid, onwetendheid en onkunde}

Suid-Afrika beleef reeds ongeveer 20 jaar 'n oorgangsfase wat aanpassings eis en wat die susterkerk-praktyk direk raak (De Wet 2000:1-4; Du Toit et al. 2002:3, 4; Pieterse 1992:328; Janse van Rensburg 2000:82,83). Die veranderings snel voort en bly die mens in sy denke (herstrukturering) deurgaans een voor (Burger 1999:8; Roxburgh 1997:26, 27; vgl. Tickle 2008:150-160). Teen hierdie agtergrond word 'n aantal sake genoem waaroor kennis skynbaar ontbreek:

- Onvolledige denke oor die Groot Opdrag (statiese aspekte oorheers in die opbou van die gemeente, terwyl dinamiese aspekte, veral uitbou bykans geen aandag kry nie). Daar is min te sien van die inherente, gebalanseerde Christus-denke (staties of dinamies) (Burger ibid:71-74, 77, 92, 93; Van Helden 2010:256-263).

- Die onvolledige denkwyse benadeel die tradisionele ekklesiologie en uitbou en vermeerdering (Dreyer 2009:7; vgl. Brouwer et al. 2007:49, 50; Hendriks 2003).

- Die Groot Opdrag beveel oop denke en vryheid vir aanpassingmoontlikhede (Burger ibid:8, 91-93; Olivier 2006:75; Runia 1988:117; Van Helden 2010:70, 71).

- Menslike denke kan nooit die waarheid van die Bybel verander nie; die Woord kan egter nuut gelees en toegepas word in veranderende tye (Burger ibid:8; Olivier 2006:75); die beginsel van nuwe wyn in nuwe wynsakke is dus hiperaktueel (Matt 9:17; Reeder 2012; Van Helden ibid:96).

- Kommer oor en 'n soeke na oplossings vir krimpende kerke ontbreek grootliks (vgl. die beperkte empiriese navorsing wat onder die susterkerke gedoen word rakende dalende getalle; Van Helden ibid).

- Tye van verandering word nie herken of reg gelees nie (Hendriks ibid).

- Onkunde oor wat veranderende tye vir die kerk inhou, wat van die kerk vereis word en die omvang van veranderende tye (Hendriks ibid; 1996:142-144; 1999:1719; Oliver 2007:23-40; Van Rooy 2006:22).

- Onstabiele tye word deur God bewerk om die evangelie te bevorder (De Klerk \& Van Helden 2011:1-10); die eb en vloed van groeitendense in die ekklesiologie behoort algemene kennis vir die kerk te wees en gelowiges moet en kan hul denke dienooreenkomstig aanpas (Hendriks 1996:142, 143; vgl. Roxburgh 1997:29-36).

- Veranderende tye moet in die lig van die Bybel nuut benader word (Kruger 2012; Niemandt 2012; Reeder 2012) en die geskiedenis moet as leerskool geneem word om 'n 'oorlewingstryd' te verhoed (Hendriks ibid).

- Weinig belangstelling word getoon in die ontwrigte mens van die een en twintigste eeu (Smit \& Vorster 2000:519521; Van der Walt 2006: 31, 32).

- Daar is min kommer oor en selfs 'n skynbaar passiewe aanvaarding van die ontsaglike groei van charismatiese bewegings as uitvloeisel van die onvolledige S-denkparadigma (Brouwer et al. ibid:38; Hendriks 1996:142, 143).

- Gereken teen die gevestigde I-denkparadigma is daar skynbaar baie min denke wat tot nuwe insigte, bekering en reformasie kan lei (Niemandt 2007:42-44).

Oorsake en gevolge van oningeligtheid, onwetendheid en onkunde: Die oorsaak van die skynbare oningeligtheid, onkunde en onwetendheid lê nie by God nie, maar by die mens se gebrekkige Godskennis, geloofstraagheid en gearriveerdheid. Kortom: die oorsaak is geleë in menslike denke. Die gevolg van die onwetendheid is dat ingekeerdheid floreer (Hendriks 2003; 1996:142-144; 1999:17-19; Oliver 2007:23-40; Van Rooy 2006:22; Van der Merwe 2009b). Van der Merwe (2009b) verwoord dit soos volg: ‘[die] praktyk bly te dikwels nog uitsluitlik na binne-gerig, lamgelê deur 'n intense fokus op die oorlewing van die eie gemeente'. Waar die kerkpraktyk só gefokus is, word ontbloot dat God en die Groot Opdrag weinig tot geen gewig dra.

Hiervolgens is die gelowige, as verbondsverteenwoordiger op aarde, nie besig met die uitvoering van die opdrag nie. Die Groot Opdrag en missionêre denke en dade word deur selfgesentreerde ingekeerdheid in die susterkerke verdring, soos onder andere bevind is deur navorsing deur Niemandt (2007:44), Van Helden (2010:297-351) en Van der Merwe (2009b). Die afwesigheid van volledige verbondsdenke oor die. Groot Opdrag, en die afwesigheid van 'n roepingsbesef wat daaruit voortspruit, verklaar die tekens van formalisme, onaanpasbaarheid, selfsug en magsug, fundamentalisme, dogmatisme, wettisisme, tradisionalisme, sakramentalisme en konserwatisme as institusionalisme, aldus Burger (1999:278) en Kirkpatrick (2011) (vgl. Schwarz 1999:99).

Ironie van illusie: Wat die toedrag van sake binne die tradisionele denke vererger, is die ironie van die 'sterk' punt, naamlik suiwer Woordnavolging deur gereformeerdes (Burger 1999:116, 121, 122; Van der Walt 2006:31; Van Rooy 2006:22; Van Rooy 2007b:32). Hulle verkeer skynbaar onder die illusie dat die tradisionele stroom se Skrifgehoorsaamheid werklik onbesproke [beyond question] is (vgl. Schwarz 1999:7; De Klerk \& Van Helden 2011:1-10; Niemandt 2007:42-44). Hierdie tradisionele aanname of denke verdring by voorbaat die moontlikheid van gewilligheid en gehoorsaamheid wat voordurend vernuwe volgens die eise van die Woord. Die aanname dat gereformeerdes suiwer en onberispelik volgens die Woord leef, word sonder om twee maal te dink, aanvaar en geglo (Hendriks 1993:548, 550:549; vgl. Tickle 2008:13-17). Sulke sekerhede word as gevolg van hierdie veronderstelling in alle eerlikheid stoer en standvastig uitgeleef in die kerkpraktyk. Eintlik openbaar dit in der waarheid gestagneerde I-denkpatrone (vgl. Niemandt 2007:54, 61-161; Van der Merwe 2009b; Van Helden 2010:300, $333,334)$. Dié denkpatroon is diep gewortel en dit sal menslik gesproke niks minder as 'n wonderwerk kos om dit om te keer nie (vgl. Tickle ibid:145-150; Van Helden ibid:136, 469). 


\section{Intensiteit}

Uit die voorafgaande bespreking is dit duidelik dat denke die beginpunt van kerkhandelinge is, en dat tekens van I-denke (institusionalisme) in'n baiehoëmatevoorkom.'n Aansienlike groep susterkerk-navorsers poog reeds geruime tyd om die intensiteit van die krisissituasie te belig. Die eenheidsisteem wat Jesus ingestel het vir die gesonde funksionering van sy liggaam, die kerk, is opsigtelik skeefgetrek in die tradisioneel Afrikaanssprekende susterkerke. Die (ontstellende) besef is dat hierdie kerke in werklikheid op 'n mank wyse dink en funksioneer. Op die keper beskou is ' $n$ halwe gehoorsaamheid net so ernstig soos 'n onbybelse kerkpraktyk, selfs al kan mense se onkunde as versagtende pleidooi aangevoer word. Die oorbeklemtoonde statiese aspekte in die opbouproses dui in der waarheid halwe gehoorsaamheid aan die Groot Opdrag. Om die oënskynlik 'suiwer' denke of kerkpraktyk weer in ewewig te kry, roep derhalwe dringend om verskeie kopskuiwe. Die bereidwilligheid om te luister, bewus te word en opnuut te interpreteer sodat opvolginsigte kan ontstaan, is noodsaaklik. Net so moet ongehoorsaamhede bely en deur bekering gevolg word. Reformasie moet 'n hoë prioriteit wees, tesame met stelselmatige verandering - spesifieke verandering wat nie oppervlakkig en korttermyngedrewe is nie en wat by die begin begin, naamlik denke (Burger 1995:13, 23-26; De Wet 2000:7; Hendriks 1996:143; 1999:19; Smit 2011; Van der Merwe 2009b).

Die krisis het ' $n$ aantal leiers in die onderskeie susterkerke in 'n mate by die punt gebring waar dade veranderde denke behoort op te volg. Die 2012-GKSA-sinode het 'n besluit geformuleer waar 'n omkeerstrategie met die Groot Opdrag as kern ter sprake is (Muller 2012). Niemandt (2012) (NG) maak ook sterk uitsprake oor 'n godsdienstige 'transformasieproses', en Smit (2011) het tradisoneel gereformeerdes tydens die 2011-Lentekonferensie ernstig gemaan om daadwerklik terug te keer tot die kern van die bekeringsproses. Die Apostolaatsbeleid (Van der Merwe 2009b) (NH) stel dit dat 'n 'skuif in die kerk se denke' moet plaasvind en dat kerkhervorming só moet geskied 'dat gemeentes gestuur' word volgens die Groot Opdrag.

Gemeet aan die Groot Opdrag, is I-denke in die gereformeerde kerkpraktyk springlewendig en openbaar dit nie bloot ' $n$ tendens nie, maar wel 'n krisistendens. Die troos is egter dat verandering van denke die toestand kan wysig. Denkverandering is nie onmoontlik nie (vgl. Rom 12:2) en dit kan wél deur menslike bereidwilligheid plaasvind (vgl. Nel 2009; Reeder 2012; Schwarz 1999, 2000; Simonian 1999). Die navorsing oor denkverandering, waaronder dié van Venter (2009), Pretorius en Lindeque van die Gereformeerde Kerk Linden en Janse van Rensburg (2009), is egter beperk binne die tradisioneel gereformeerde susterkerke omdat die denke van die susterkerke grootliks nog nie op verandering fokus nie. Bewusmaking van die noodsaaklikheid van verandering is derhalwe uiters belangrik.

\section{Denkveranderingsproses}

Die eerste vraag wat op hierdie stadium in 'n susterkerklidmaat se gedagtes opkom, is: Hoe is verandering van denke enigsins moontlik? Die kerkpraktyk is immers dekades lank al deur I-denke gevestig. Daarby het die tradisionele gelowige in sy denke oënskynlik geen ander verwysingsraamwerk nie.

\section{Die Skrif as verwysingsraamwerk}

Romeine 12:2 bied nie net die langtermyn-oplossing nie, maar gee ook 'n werkbare opdrag aan die mens. Die werkwoord in Romeine 12:2, naamlik verander (metamorfose), is in die teenwoordige tyd en wys dat verandering nou as 'n voortdurende proses bedoel word. Hierdie Skrifgedeelte wys daarop dat Jesus die metamorfose of verandering of omkeer deur sy verlossingswerk bewerkstellig het (indikatief), maar dat die veranderingsproses terselfdertyd bly voortgaan. Die werkwoord is egter ook in die passiewe vorm. Dit toon aan dat die aksie van verandering in die mens bewerk word - sonder die mens se toedoen. Die gedagte van verandering ontkiem wel in die mens se denke, maar slegs deur die vernuwende werk van die Heilige Gees in die mens se onderbewuste (Strong 2007:59, 103). Die vorm van die werkwoord is egter ook in die imperatiewe vorm. Om te verander en soos Christus te word (indikatief), is ' $n$ bevel aan die mens. Die bevel roep die mens op tot ' $n$ verandering, tot ' $n$ wilsbesluit wat dan bevestig word deur dade as resultate van die vernuwende denke. Die imperatief, gelees in die lig van Filippense 2:12 en 13 , toon die 'onnaspeurlijke' werk wat verandering moontlik maak (Strong 2007:107-110, 128).

Godgewilde verandering in die gewillige mens word sodoende bewerkstellig (2 Kron 15; Fil 2:12, 3). In die woorde van Van Ruler (Park 1995:20) is gelowige verandering, met ander woorde, werklike diep bekering, altyd 'n verbondsmatige 'onnaspeurlijke' genadehandeling (vgl. Strong 2007:52, 59, 107-110, 445).

\section{Die herontdekte Skrifwoord Vooraf-proses}

Ware denkverandering kan slegs plaasvind as die mens 'n vooraf-proses deurtrap en deurvoer, sonder om na die ou weë terug te keer. Die vooraf-proses behels (1) erkenning van die heersende toestand, (2) eerlike en deurtastende selfondersoek en (3) die bewustelike besef dat die uitweg diep en drastiese verandering (Van Helden 2010:366-372; vgl. Reeder 2012) is, terug na die volledige en gebalanseerde Christosentriese denkparadigma (statiese en dinamiese benadering in opbou én uitbou van die gemeente). En bowenal dat daar geen alternatief bestaan nie (Tickle 2008:143; Van der Merwe 2009b; Niemand 2007).

Die pad weg van skynbare oningeligtheid, onkunde en onwetendheid tot by erkenning, selfondersoek en 'n helder insig in wat nodig is, is op sigself ' $n$ diepsnydende en tydrowende proses. Diegene wat eenderse emosies ervaar, groepeer saam voordat die proses rasioneel deurloop is (stoomrollerproses) (Burger 1999:313; Brouwer et al. 2007:49). Die proses word in Figuur 1 uiteengesit. 


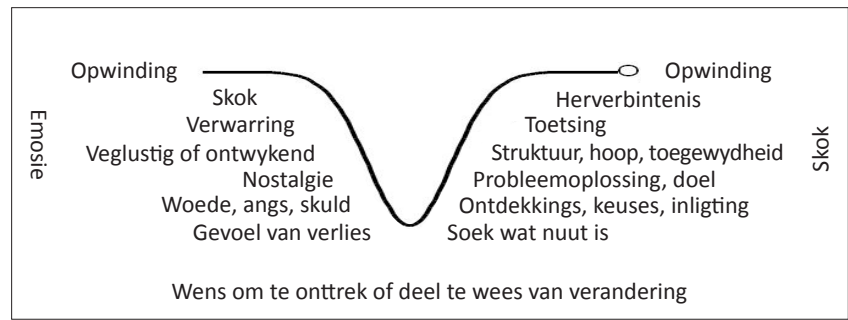

FIGUUR 1: Die stoomrollerproses.

In die proses bereik sodanige emosies en menings die media gereeld voordat die daarvoor bedoelde kanale bereik word (vgl. Jackson 2012). Verandering en gepaardgaande emosies geskied immers by die mens individueel en nie volgens 'n vasgestelde tempo nie.

Die nood moet werklik erken word. Dit moet gepaard gaan met diepgaande selfondersoek en 'n eerlike besef dat verandering terug na die Tweepolige (staties of dinamies) Christosentriese denkraamwerk die enigste uitweg is. Dit is dan eerstens die predikant en leiers en mettertyd die lidmate se taak om as bereidwillige en goeie bestuurders die hand aan die ploeg te slaan. Dan word die huishouding van God volgens sý bepalings of voorskrifte aangepak, en werk gelowiges sonder agtertoekyk voortdurend in die rigting van 'n volhoubare gesonde kerkterreinwerk (Tit 1:3, 5; Ferreira et al. 2012).

Eerste moet ' $\mathrm{n}$ bereidheid om te verander, ontwikkel; die vooraf-proses fokus dus op ménslike denke. Wat hier ter sprake is, is deur en deur menslike optrede (Schwarz 1999; 2000). Hierdie nuwe, veranderende raamwerk voed skeptisisme, vrees (Pretorius en Lindeque 2009) en onsekerhede. Mense het nie voldoende kennis, ervaring en bevoegdheid vir dié nuwe lewe nuwe leefwyse nie (vgl. Ferreira et al. 2012). Navorsing by die NG Kerk Sonder Mure (Venter 2009), die Gereformeerde Kerk Linden (Pretorius en Lindeque 2009) en NH Kerk Zuurfontein (Janse van Rensburg 2009; vgl. Dreyer 2009), bevestig dat die veranderingsproses nie ' $n$ gelyke, geplaveide paadjie is nie.

God as Verbondsgod eis egter nooit iets van die mens as Hy nie eers voorsien nie. In die proses om mense se denke te wysig, met ander woorde, onderweg na bekering van denke, bied Hy ook die instrumente om dit mee aan te pak.

\section{Instrumente}

Die instrumente wat die mens in die veranderingsproses gebruik, is nie 'n nuut uitgedinkte menslike produk nie. Inteendeel. Dié instrumente is in die Skrif te vinde. Hulle bring dus nie 'n nuwe waarheid nie; dis bloot 'n herontdekking van 'n reeds bestaande manier om die waarheid te laat spreek (Chaffee 2004:10). Begeleidende gebed en die voortdurende bewustheid van die nuwe-wyn-nuwe-sak-beginsel is noodsaaklik (Matt 19:17; Reeder 2012). Dié wegspringpunt toon verbondsafhanklikheid in 'n gesindheid waar die Woord nuut spreek binne die huidige tydvak: 'n spreke van dankbaarheid en waardering, en om te doen wat reg en goed en aanneemlik is vir God (Rom 12:1, 2; Niemandt 2007:69, 70).
Dankbaarheid en waardering: Vir iemand wat bereid is om te verander en inderdaad daartoe oorgaan, is dankbaarheid die positiewe en waarderende beginpunt (1 Tess 1:2, 3; Branson 2004:xi, 40,43-58). Branson (2004) verwys ook na Nouwen, wat dankbaarheid sien as 'n dissipline en keuse:

- The discipline of gratitude is the explicit effort to acknowledge that all $1 \mathrm{am}$ and have is given to me as a gift of love, a gift to be celebrated with joy. Gratitude as a discipline involves a conscious choice. 1 can choose to be grateful even when my emotions and feelings are still steeped in hurt and resentment. [Die dissipline van dankbaarheid is die uitgesproke poging om te erken dat alles wat $e k$ is en het, as 'n liefdesgawe aan my gegee word, 'n geskenk om met blydskap te vier. Dankbaarheid as dissipline behels ' $n$ bewuste keuse. Ek kan kies om dankbaar te wees selfs wanneer my emosies en gevoelens nog deurdrenk is van pyn en wrewel.] (bl xi, 40, 43-58, [outeur se eie vertaling])

- Ook Paulus se briewe begin deurgaans met dank as deel van die goeie, voordat enige ander saak aangespreek word (o.a. 1 Tess 1:2).

- Die sewe briewe in Openbaring, wat die universele kerk se goeie en swak punte uiteensit, fokus eers op Jesus se positiewe en waarderende invalshoek: 'Ek ken jou werke ...' (Openb 2:19). Die negatiewe word nietemin nie vermy nie, maar deur die wyse van benadering word die mens na die ontdekking van God se lig gerig, ten spyte van negatiewe omstandighede (vgl. Ps 139) (Chaffee 2004:2, 10).

- Waardering as benadering of instrument is deur Jesus toegepas. Hy hef die mens telkens waarderend op en rig die nuwe mens positief verder tot 'n volgende menslike aktiwiteit (Matt 5:14, 15) wat vir God aanneemlik is.

Die kommunikatiewe taal-aanslag maak gebruik van vraagstelling as instrument:

- Vraagstellling: Jesus het grootliks positiewe kommunikasie in kombinasie met vraagstelling gebruik. Deur positiewe taalgebruik word kennis (wat reeds in die mens se denke bestaan, praksis 1), deur die vraag-antwoordmetode (vertelling) by die mens se denke gevoeg (bewusmaking en leer). Dit bewerkstellig groei, verandering in die gedagtegang en denke met ' $n$ verbeterende toedrag van sake (praksis 2) as uitkoms. Slegs enkele Skrifvoorbeelde word gegee: Jesus se kommunikatiewe benadering tydens die gesprek met die Samaritaanse vrou (Joh 4:1-26); die vermeerdering van die brode en visse (Mark 6:35-44; Mark 8:1-10); die belydenis van Petrus (Mark 8:27-30); die vraag oor die betaal van belasting (Mark 12:13-17); die blinde man by Jerigo (Luk 18:35-43); en die gelykenisse. Niemandt (2007:70, 89) verwoord vraagstelling as taalinstrument soos volg: 'Waarderende ondersoek is 'n proses van geestelike onderskeiding wat mense vorm deur die regte vrae te stel.'

Die positief-waarderende aanslag tesame met vraagstelling in die Skrif word soos volg aangewend: God het geskep en dit was baie goed (Gen 1:31). Die negatiewe vraagstelling deur Satan $($ Gen 3:1,4) laat negatiewe denke by die mens posvat. Negatiewe denke ontwikkel deur negatiewe kommunikatiewe kennistoevoeging en die mens, as 
verteenwoordiger van God, misluk (Gen 3:4-6). Deur bewus te word (te leer) van die goeie en positiewe, asook van die kwade en negatiewe (Gen 2:9, 3:6, 11), het die mens die vermoë gekry om sy denke deur kennis en keuses te verander. Deur positiewe vraagstelling soek God die mens eerste op (Gen 3:8) en ten spyte van menslike mislukking, gee God die moederbelofte wat 'n veranderde, positiewe omstandigheid beloof (Gen 3:15). Deur Christus vind positiewe herskepping plaas (Rom 6:1-10). Die verlore mens word deur die kragtige inwerking van die Gees gelei om positiewe keuses te maak wat sy denke vernuwe en van hom 'n nuwe skepping maak (Rom 8:1-17).

Die kommunikatiewe taal-aanslag beweeg dan verder deur die instrument van menslike beplanning (as opdrag) toe te voeg:

- Voortdurende veranderende, aanpassende optrede en beplanning as opdrag: Rom 12:1 en 2 (Nuwe Vertaling) handel oor die veranderende, positiewe nuwe lewe in Christus: 'Laat God julle verander deur julle denke te vernuwe, dan sal julle ook kan onderskei wat die wil van God is, wat vir Hom goed en aanneemlik en volmaak is.' Fil 4:8 (Nuwe Vertaling) fokus op deugde en lofwaardige sake wat waar, edel, reg, rein, mooi en prysenswaardig is: 'daarop moet julle julle gedagtes [denke] rig'. Dit is die verbondsmens se verantwoordelikheid om met sy denke biddend en onderskeidend te werk te gaan en sy gedagtes positief-Christosentries te rig. Dit is dus doodeenvoudig die hedendaagse gelowiges se taak om hul eie denke en optrede of beplanning 'uit te werk met vrees en bewing' (Fil 2:12 Nuwe Vertaling) in die volle waarheid van die Groot Opdrag, want dit is in der waarheid God wat hulle 'gewillig en bekwaam maak om sy wil uit te voer' (Fil 2:13 Nuwe Vertaling).

Watter omstandighede ook al in Suid-Afrika die botoon voer (De Klerk \& Van Helden 2011:1-10), word in die lig van die Skrif geringer geag, aangesien die gelowige, wat positief Christusgesentreerd ingestel is, tydig en ontydig 'tot alles in staat is deur Hom' wat die Heilige Gees as krag aan die mens gee (Fil 4:13). Die positiewe word in Titus 3:9-11 en 1 Tessalonisense 5:21, 22 beklemtoon, deurdat die gelowige niks te doen moet hê met enige negatiewe saak nie. Passiwiteit, introversie en verknogtheid aan die status quo is bewese negatiewe sake binne die problematiese ekklesiologie. Dit spruit uit die denke van die verbondsmens wat toegee aan negatiewe sake. Deur aan negatiewes toe te gee, ontken die mens die krag wat deur die Heilige Gees verbondsmatig in hom is, asook die belofte wat tydens die verbondsdoop verseël is.

Dié herontdekte Skrifaanslag (Strong 2007:106; Niemandt 2007:69, 70) staan bekend as Waarderende Ondersoek (WO) en dien wêreldwyd as geskikte en waardevolle manier om diep, stelselmatige en volhoubare denkverandering te laat plaasvind. Die waarderend-positiewe kommunikatiewe taalaanslag vergemaklik die 'oopmaak' van bestaande kennis en ervarings, wat dan lei tot leer in die betrokke situasie (WObenadering in Niemandt 2007). 'n Kettingreaksie ontstaan deurdat leer energie ontsluit wat die mens op organiese wyse vorentoe stuur en tot die agogiese moment (wilsbesluit) lei. Hieruit ontspring konstruktiewe menslike inisiatiewe of optrede. So 'n gesindheid, wat terselfdertyd ook die proses is (Branson 2004:xi, xii; 37-40; Cooperrider et al. 2008:3-5, $7-10)$, bewerkstellig volhoubare beweging in die rigting van gesonde verwagtings.

Hierdie beweging is nie ' $n$ probleemoplossende proses nie, maar wel 'n beweging wat deur waardering van kragte deur menslike taal en menslike verhoudings bewerk word. Blywende verandering kan bewerkstellig word (Branson 2004:19; Van Helden 2010:372-380) indien die mens konsekwent daarmee volhou. Hierdie beweging kan die ontdek-, droom-, ontwerpen bestemmingsaktiwiteite genoem word, ook bekend as die 4D-aktiwiteite (Chaffee 2004:13, 14; Cooperrider et al. 2008:5, 25, 26-31, 42-47, 69, 73; Van Helden 2010:539-555; Van der Merwe 2009a; Niemandt, 2007).

Die taal-aanslag verander denke op'n natuurlike en organiese wyse. Mettertyd, indien die mens daarmee volhou, raak 'n Christosentriese denkwyse gevestig, waarbinne die Gees saam met Christus herskeppend wil meewerk (Cooperrider et al. 2008). Die méns word immers deur die Skrif aangeraai om 'n byl wat stomp is, te slyp (Pred 10:10). Die tradisionele ekklesiologie, wat grootliks gedryf word deur I-denke, vertoon 'stomp' en roep ernstig om deur niemand anders nie as die mens self geslyp te word (vgl. Branson 2004:xiii).

\section{Die Christosentriese denkparadigma}

Die wil om Christosentries te dink en te doen, is die gebalanseerde derde en sentrale denkparadigma wat tussen die I- en S-paradigmas staan, aldus Schwarz (1999:71, 218220). Die Christosentriese denkparadigma toon, soos reeds bespreek is, tweepolige kenmerke. 'n Gesonde kerkpraktyk wat die krisis kan ontlont, het 'n drieledige strategie:

1. die Groot Opdrag as sleutel

2. die tweepolige Christosentriese denkparadigma

3. die WO-taalaanslag.

Dit kan voortdurende golfbewegings (De Klerk \& Van Helden 2011) wat buite die mens se beheer is, weerstaan. Figuur 2 gee 'n samevatting van die drie denkparadigmas (Schwarz 1999:71, 218-220).

\section{Sleutelbeginsels}

Die antwoord oftewel sleutel vir gesonde kerke is deur Jesus self aan sy kerk gegee in die Groot Opdrag. Die indikatief en imperatief wat in die opdrag geleë is, vorm vandag steeds die missie van die kerk (groei en uitbreiding) - missio Dei en missio ecclesiae. Meer spesifiek dui die missie op die opbou en uitbou as eenheidsproses binne die kerkpraktyk soos bedink en uitgevoer deur mense.

\section{Bybelse begronding}

Efesiërs 4, Romeine 12 en 1 Korinthiërs 12 beskryf die kerk as lewende organisme. Kuyper voer aan dat indien die kerk nie as organisme funksioneer nie, neem verval in die kerk toe en is tekens van institusionalisme onafwendbaar 


\begin{tabular}{|c|c|c|c|}
\hline S-paradigma & Tweepolige teol & jiese paradigma & I-paradigma \\
\hline Dualisme & Dinamiese pool & Statiese pool & Monisme \\
\hline $\begin{array}{l}\text { organies dinamies } \\
\text { sag biologies intuïtief vroulik holisties } \\
\text { induktief }\end{array}$ & $\begin{array}{c}\text { (produseer die statiese pool) } \leftarrow \\
\text { Organies }\end{array}$ & $\begin{array}{c}\text { (stimuleer die dinamiese pool) } \\
\text { Organisatories }\end{array}$ & $\begin{array}{l}\text { organisatories staties hard nie-animaties } \\
\text { tegnologies rasioneel kop manlik analities } \\
\text { deduktief }\end{array}$ \\
\hline
\end{tabular}

FIGUUR 2: Drie denkparadigmas.

(Dreyer 2009:27). Malphurs (2004:9) en Reeder (2012) voeg hierby toe dat groei sal toeneem as die kerk Bybels ingelig, kultureel relevant en as lewende organisme gesond is.

1 Korinthiërs 3:6 verwys na natuurlike of organiese groeiomstandighede: 'Ek het geplant, Apollos het natgegooi, maar dit is God wat laat groei' (Walls 2002:14; Reeder 2012). Wanneer onvolledige denke dus in die ekklesiologiese eenheidsisteem kop uitsteek, belemmer dit die moontlikhede vir groei (Schwarz 1999). Volgens die Woord is daar egter volkome harmonie tussen organiese en organisatoriese elemente. Dié harmonie toon derhalwe aan hoe gesonde denke en 'n gesonde kerkpraktyk daar uitsien (vgl. navorsing gedoen deur De Kock 2003:17). Die balanserende Christosentriese denk- en werkswyse word deur Jesus geleef, byvoorbeeld wanneer Hy die kerk as lewende stene (1 Pet 2:4-8) beskryf. Die dinamiese aspek word deur lewende aangedui, terwyl die statiese aspek deur stene aangedui word. Ander voorbeelde is onder andere Efesiërs 2:19-22 en 1 Korinthiërs 3:9.

Alhoewel meer voorbeelde bestaan, word slegs enkeles hier opgenoem om die Bybelse begronding van die Christosentriese benadering, aan die hand van die dinamiese en statiese pole binne ' $n$ eenheidsisteem (opbou en/of uitbou), aan te toon (De Kock 2003). Om alle vlakke van die ekklesiologie te dek, is aansluiting gevind by die struktuur en navorsing wat Schwarz (1999) reeds ongeveer 30 jaar doen oor gesonde kerke, kerkkrimping en kerkgroei (vgl. De Kock ibid). Deur hierdie navorsing is vasgestel dat agt meetbare, Skrifbegronde kenmerke by alle kerke voorkom wat gebalanseerd ontwikkel en gesonde groei toon (De Klerk \& Van Helden 2011:1-10; De Kock ibid:28-82).

Elkeen van die agt kenmerke binne 'n gesonde kerkpraktyk word deur 'n byvoeglike naamwoord (dinamiese pool), en deur 'n selfstandige naamwoord (statiese pool) geformuleer. Die twee pole dien as riglyne in menslike denke en beplanning en funksioneer as 'n eenheidsisteem om op natuurlike wyse balanserende opbou (gemeentevorming) en uitbou (evangelisasie of sending) daar te stel.

Hieronder is slegs enkele Skrifverwysings vir die balanserende elemente as Christosentriese denkwyse oor die kerkpraktyk:

- Passievolle spiritualiteit: 1 Korinthiërs 12:31; Openbaring 2:4, 3:15, 16

- Gawe-georiënteerde bediening: 1 Korinthiërs 12; Romeine 12; Efesiërs 4; 1 Petrus 4, Heidelbergse Kategismus, Sondag 21, vraag/antwoord 55, formulier vir die aflegging van belydenis van geloof (5)

- Aanbidding: Johannes 4:24; Efesiërs 5:18-21, Psalm 95:1-6
- Holistiese kleingroepe: Handelinge 2:46, 1 Korinthiërs 16:19

- Behoeftegeoriënteerde evangelisasie: Filippense 2:15, 16; Mattheus 9:35; Markus 6:11, 12

- Funksionele strukture: Mattheus 7:24-27

- Bemagtigende leierskap: Efesiërs 4:12, 4:13-16

- Liefdevolle verhoudings: 1 Korinthiërs 13; Mattheus 5.

Die koninkryk van God is, in menslike terme, die 'droom' van God (Niemandt 2007:163). Met die wederkoms sal dit verwerklik word wanneer die gesonde grond die goeie saad en vrug toon. Totdat dit gebeur, het die mens die taak (wat by denke begin) om álles moontlik te bedink en te doen om die kerkpraktyk so gesond moontlik te hou, om hindernisse bewustelik te beperk en op verantwoordelike wyse uit die weg ruim (vgl. Nel 2009; Reeder 2012). Veranderende denke kan die denkkrisis mettertyd ontlont.

Uitbreiding op WO en die fyner besonderhede van die veranderingsproses ter wille van die vestiging van 'n Christosentriese denkwyse wat waarlik tot 'n veranderende kerkpraktyk kan lei, vereis ter wille van volledigheid die moontlikheid van 'n verdere opvolg-artikel.

\section{Slot}

I-denke binne die tradisioneel Afrikaanssprekende susterkerke is grootliks verantwoordelik vir die onvolledige en ongebalanseerde uitvoering van die Groot Opdrag wat oor jare ' $n$ ongesonde kerkterrein gekweek het. Binne hierdie krisissituasie is dit noodsaaklik om te besef dat alles menslik moontlik gedoen moet word om die kerkpraktyke wat oor jare deur gevestigde menslike denke en dade ontwikkel het, te vervang met denke en dade wat sprekend is van die balanserende riglyne in die Groot Opdrag. Die huidige ekklesiologiese krisis, waar uitbou of vermeerdering grootliks ontbreek, kan ten diepste toegeskryf word aan die heersende I-denkparadigma. Hierdie situasie kan begin verander wanneer gereformeerdes besef hoe dringend die krisis is en bewustelik die mens se kant van die verbondsopdrag begin nakom. Die hoop beskaam nie en 'n vooraf-proses kan tot hartgrondige bekering lei. Die sleutel terug na suiwer en volledige navolging van die Woord word herontdek deurdat die Skrif, aan die hand van die Groot Opdrag en WO, die mens in die krisis lei tot ' $n$ Christosentriese denkparadigma. Dit is ' $n$ denke wat stelselmatig en volhoubaar in die kerkpraktyk toegepas kan word: 'n denkparadigma wat tot voordeel van al die nasies in hierdie land - as uithoek van die aarde - kan uitkring.

\section{Literatuurverwysings}

Beukes, A.P.J., 2007, Almanak, Jaargang 101, SENTEK.

Branson, M.L., 2004, 'Memories, Hopes and conversations; Al and congregational change' viewed n.d., from http://books.ekklesia.co.uk/product_info. php?products_id $=2081$ 
Bosch, D.J., 1991, Transforming mission - Paradigm shifts in theology of mission, Orbis Books, New York.

Botha, G.N.V., 2006, 'Altyd reformerend! Die GKSA se roeping ook in 2006', Die Kerkblad, Oktober, 22-23.

Brouwer, R., De Groot, K., De Roest, H., Sengers, E. \& Stoppels, S. (reds.), 2007, Levend liggaam: Dynamiek van christelijke geloofsgemeenschappen in Nederland, Kok, Kampen.

Burger, C., 1995, Gemeentes in transito - vernuwingsgeleenthede in 'n oorgangstyd, Lux Verbi, Kaapstad.

Burger, C., 1999, Gemeente en bediening 4: Gemeentes in die Kragveld van die Gees oor die unieke identiteit, taak en bediening van die kerk van Christus, BUVTON Stellenbosch.

Cameron, H., Richter, P., Davies, D. \& Ward, F., 2005, Studying local churches: A handbook, SCM Press, London.

Chaffee, P., 2004, 'Claiming the light: appreciative inquiry and congregational transformation', viewed 10 June 2008, from www.congregationalresources.org/ Appreciative/Introduction

Cooperrider, D., Whitney, D. \& Stavros, J., 2008, Appreciative Inquiry Handbook for leaders of change, 2 nd. edn., Crown Custom Publishing, Inc., Ohio.

De Bruyn, F.R.P., 1989, Almanak van die Gereformeerde Kerke in Suid-Afrika, Jaargang 115, Potchefstroom Herald, Potchefstroom. PMCid:260779

De Klerk, B. \& Van Helden, P., 2011, 'Oorsake van kerkkrimping binne die tradisionee Afrikaanssprekende gereformeerde kerke in Suid-Afrika', Verbum et Ecclesia 32(1) 1-10. http://dx.doi.org/10.4102/ve.v32i1.477

De Kock, H.K., 2003, "n Prakties-teologiese beoordeling van Natural Church Development se agt kwaliteitseienskappe van groeiende kerke', MA tesis, Potchefstroomse Universiteit vir Christelike Hoër Onderwys (NWU), Potchefstroom.

De Wet, F.W., 2000, 'Geloofswaarneming - 'n Teologies-estetiese benadering to Praktiese Teologie', PhD proefskrif aan die Potchefstroomse Universiteit vir Christelike Hoër Onderwys (NWU), Potchefstroom.

Die Kerkblad, 2007, 'Teologiese studente doen sendingprakties', April, 41

Dreyer, P.S., 1990, Almanak, Jaargang 84, Gutenberg, Pretoria-Wes.

Dreyer, W.A., 2009, "n Prakties-teologiese perspektief op kerkwees met besondere verwysing na die Nederduitsch Hervormde Kerk van Afrika', PhD proefskrif, Universiteit van Pretoria, Pretoria.

Du Toit, B., 2008, 'Kerkspieël, die kerk se vriend of vyand?' Kerkspieël, April, 1.

Du Toit, F., Hofmeyr, H., Strauss, P. \& Van der Merwe, J., 2002, Moeisame pad na vernuwing: Die NG Kerk se pad van isolasie en die soeke na 'n nuwe relevansie, Barnabas, Bloemfontein.

Ferreira, N., Bogaarts, A., Verhoef, A., Dekker, H., De Kock, D., Venter, K. et al., 2012, "n Gesprek oor hoe om missionaal te wees vanuit/binne 'n gereformeerde tradisie', Reformissio, gebruik op 15 Junie 2012, by http://www.facebook.com/groups/ reformissio/

Fellows, A., 2007, Paganism Strikes Back: the Return of Ancient Spirituality, viewed 18 June 2012, from http://www. bethinking.org/resource.php?ID=329\&TopicID=7\&C ategorylD=7; http://www.bethinking.org/download.php?MedialD=853

Gaum, F., 1990, Jaarboek van die Nederduitse Gereformeerde Kerke, Jaargang 141, Nasionale Boekdrukkery, Kaap.

Gaum, F., 2000, Jaarboek van die Nederduitse Gereformeerde Kerke, Jaargang 151, Tydskriftemaatskappy van die NG Kerk, Tygervallei. PMid:10754080

Gill, R., 2003, The 'Empty' Church Revisited, Ashgate, Burlington.

Gilbert, M.G. \& Brock, R.T. (eds.), 1985, The Holy Spirit \& Counseling, Hendrickson Publishers, Massachusetts.

Giliomee, H., 2004, Die Afrikaners 'n Biografie, Tafelberg, Kaapstad.

Heitink, G., 1979, Pastoraat als hulpverlening: inleiding in de Pastorale Theologie en Psychologie, 2de druk, Uitgeversmaatschappij, J.H. Kok, Kampen. PMid:256334

Heitink, G., 1999, Practical Theology History Theory Action Domains: Manual for Practical Theology, tranls. R. Bruinsma, William B. Eerdmans Publishing Company, Cambridge.

Hendriks, H.J., 1993, 'Die 1991-bevolkingsensus-tendense en die Afrikaanse kerke', Nederduits Gereformeerde Teologiese Tydskrif 34(4), 542-551.

Hendriks, H.J., 1996, 'Kerkspieël en die NGK statistiek in die wyer perspektief van die Suid-Afrikaanse bevolkingsensusse 1911-1991', Nederduits Gereformeerde Teologiese Tydskrif 37(1), 138-145.

Hendriks, H.J., 1999, 'Verwagting vir die nuwe millennium: Gaan Gereformeerde Kerke groei, kwyn of verdwyn?' Woord en Daad, Lente 13, 17-19.

Hendriks, H.J., 2000, 'Tussen ideologiese ontnugtering en 'n nuwe visie. Waarom Afrikaners se wiele pap is' Tydskrif vir Geesteswetenskappe 40(4), 1-5.

Hendriks, H.J., 2003, Die toekoms van die kerk, die kerk van die toekoms, gebruik op 10 Mei 2010, by http://academic.sun.ac.za/theology/Profiles/Profile documents/ Prof_Jurgens_Hendriks_Intreerede.pdf

Hofmeyr, J.W. \& Pillay, G.J. (eds.), 1994, A History of Christianity in South Africa, volume 1, HAUM Tertiary, Pretoria.

Jackson, N., 2012, Stryd oor sewe punte, gebruik op 12 Junie 2012, by http://www. beeld.com/In-Diepte/Nuus/Stryd-oor-sewe-punte-20120611

Janse van Rensburg, J., 2000, The paradigm shift. An introduction to postmodern thought and its implications for theology, Van Schaik, Pretoria.
Janse van Rensburg, J.G., 2009, e-pos, geen datum, hannes@netwindow.za.net Jones, C., 2008, 'In institusionele gevangenis vasgevang?' Kruisgewys, April, 13.

Kirkpatrick, J., 2011, 'Gereformeerde identiteit-droom, werklikheid of oriëntasiepunt, voordrag gelewer as deel van Excelsus se 6de konferensie, Universiteit van Pretoria, Suid-Afrika, 20-22 September.

Kruger, P., 2012, 'Die beginsels van Gereformeerde Hermeneutiek en die uitdagings daarvoor in ons huidige konteks', voordrag gelewer as deel van ' $n$ paneel tydens die gespreksgroepbyeenkoms van die Fakulteit Teologie, Noord-wes Universiteit, Potchefstroom, 20 April.

Louw, W., 2012, Antwoord op prof. Nelus Niemandt se artikel in Kerkbode 16/03/2012, gebruik op 14 Junie 2012, by http://hierstaanek.com/2012/03/14/antwoord-opprof-nelus-niemandt-se-artikel-in-kerkbode-16032012/

Lotter, G.A. \& Thompson, G.G., 2005, 'Acts 17:16-34 as paradigm in responding to postmodernity', In die Skriflig 39(4), 695-714. http://dx.doi.org/10.4102/ids. v39i4.410

Malan, J., 2004, Spiritual decline in Calvinistic Churches: spiritual decline in Reformed churches in S.A., viewed 15 May 2012, from http://www.bibleguidance.co.za/ Engarticles/Decline.htm

Malphurs, A., 2004, Planting growing churches for the 21st century, Baker Books, Grand Rapids.

Meylahn, J., 2011, 'Postmodernisme in multikulturele konteks - identiteit in die skadu van die kruis', voordrag gelewer as deel van Excelsus se 6de konferensie, Lente in Bediening en Teologie, Universiteit van Pretoria, 20-22 September.

Muller, R.J., 2012, Beskrywingspunt streeksinodes Vrystaat en KwaZulu-Natal Omkeerstrategie, gebruik op 25 Januarie 2012, by http://www.gksa.org.za/ Sinodes/Sinode $2012 / \mathrm{pdf} / 25.4 \% 20$ Beskrywingspunt\%20-\%200VS\%20-\%20 Omkeerstrategie.pdf

Nel, M., 2009, Congregational analysis revisited: Empirical approaches, viewed 10 May 2010, from http://www.scielo.org.za/scielo.php?pid=S025994222009000100033\&script=sci_arttext

Niemandt, N., 2007, Nuwe drome vir nuwe werklikhede, Lux Verbi BM, Barnabas, Bloemfontein.

Niemandt, N., 2012, Nuwe bedeling en nuwe lewe, gebruik op 13 April 2012, by http://www.beeld.com/Rubrieke/Gasrubriekskrywers/Nuwe-bedeling-en-nuwehttp://www.bee

Oliver, E., 2007, 'Thoughts on writing Afrikaner church history in the 21st century', Studia Historiae Ecclesiasticae xxxiii(1), 23-40.

Olivier, I.J., 2006, 'The strategic task of the church in creating spaces for spirituality', $\mathrm{PhD}$ thesis, North-West University, Potchefstroom.

Park, T., 2005, 'The sacred rhetoric of the Holy Spirit: a study of Puritan Preaching in a Pneumatological Perspective' (met een samenvatting in het Nederlands), Proefschrift by Apeldoorn Theologische Universiteit, Apeldoorn.

Pieterse, H.J.C., 1992, 'Woord en werklikheid in die moderne Praktiese Teologie', In die Skriflig 26(3), 325-335.

Reeder, H.L., 2008, The leadership dynamic A Biblical Model for raising effective leaders, Crossway Books, Illinois.

Reeder, H.L., 2012, 'From embers to a flame. How God can revitalize your church', paper delivered at From embers to a flame-konferensie, Good News Convention Centre, Muldersdrif, 08-10 Mei.

Roxburgh, A.J., 1997, The missionary congregation, leadership and liminality, Trinity Press International, Harrisburg.

Runia, K., 1988, Waar blijft de kerk? , Uitgeversmaatschappij J.H. Kok, Kampen.

Pretorius, M., 2006, 'The theological centre of Pauline theology as it relates to the Holy Spirit', HTS Teologiese Studies/Theological Studies 62(1), 253-262. http:// dx.doi.org/10.4102/hts.v62i1.354

Saarinen, M.F., 1992, The life cycle of a congregation, The Alban Institute, New York City.

Schalekamp, M.E., 2005a, 'Multikulturele kerkplanting Ons moet hande vat met ander gelowiges en kerke', Die Kerkblad, Augustus, 24-27.

Schalekamp, M.E., 2005b, 'Missiones Ecclesiae: 'n missionêre visie en strategie in gemeentebou ten opsigte van multikulturele kerkplanting', PhD-proefskrif, Noordwes Universiteit, Potchefstroom. PMCid:1884901

Schalekamp, M.E., 2005c, Almanak, Gereformeerde Kerk in Suid-Afrika. Potchefstroom. PMCid:1884901

Schwarz, C.A., 1999, Paradigm shift in the church-How natural church development can transform theological thinking, ChurchSmart Resources, Emmelsbüll.

Schwarz, C.A., 2000, Natural Church Development: A guide to eight essential Qualities of Healthy churches, S.A. Church Wise, Randhart.

Schwarz, C.A. \& Schalk, C., 1998, Implementation guide to natural church development, S.A. Church Wise, Randhart.

Simonian, C., 1999, Natural Church Development: A Review - A book by Christian Schwarz, viewed 10 May 2010, from http://www.ourvineyard.org/files/A Review_of_Christian_Schwarz1.htm

Smit, D., 2011, 'Wie is ons? Oor ons Gereformeerde identiteit', voordrag gelewer as deel van Excelsus se 6de konferensie, Lente in Bediening en Teologie, Universiteit van Pretoria, Suid-Afrika, 20-22 September.

Smit, C.J. \& Vorster, J.M., 2000, 'Die GKSA en sy gereformeerde identiteit: Kan dit behou word in 'n postmoderne gemeenskap?' In die Skriflig 34(4), 515-533. http://dx.doi.org/10.4102/ids.v34i4.613

Storm, J.G.M., 2001, Almanak, Jaargang 95, SENTEK. 
Storm, J.G.M., 2005, Almanak, Jaargang 99, SENTEK.

Strong, P., 2007, 'Romans $12: 2$ as an important paradigm for transformation in a Christian: a practical theological study', PhD thesis, North-West University, Potchefstroom.

Symington, J., 2005, Jaarboek van die Nederduitse Gereformeerde Kerke, Jaargang 156, Tydskriftemaatskappy van die NG Kerk, Wellington.

Symington, J., 2007, Jaarboek van die Nederduitse Gereformeerde Kerke, Jaargang 158, Tydskrifmaatskappy van die NG Kerk, Wellington.

Tickle, P., 2008, The great emergence, Baker Books, Michigan. PMCid:2529376

Van der Merwe, C., 2009a, e-pos, 03 Maart, christo@kpo.co.za

Van der Merwe, C., 2009b e-pos, 26 Februarie, christo@kpo.co.za

Van der Merwe, J., 2011, 'Terug na die toekoms: Ontdek wie ons regtig is!' voordrag gelewer as deel van Excelsus se 6de konferensie, Lente in Bediening en Teologie Universiteit van Pretoria, Suid-Afrika, 20-22 September.

Van der Walt, S.J. (e.a.), 2000, Almanak van die Gereformeerde Kerke in Suid-Afrika, Jaargang 126, United Litho, Potchefstroom.
Van der Walt, B.J., 2006, 'Die Postmodernisme, 'n verleentheid en 'n geleentheid', Die Kerkblad, September, 30-32.

Van Helden, S., 2010, "n Hermeneuties-empiriese strategie rakende die verskynse van kerkkrimping in tradisioneel Afrikaanse "susterkerke" in Suid-Afrika - 'n prakties-teologiese studie', PhDtesis, Noordwes Universiteit, Potchefstroom.

Van Rooy, J.A., 2006, 'Ons sendingerfenis ... en die vrugte na 100 jaar', Die Kerkblad, September, 21, 22

Van Rooy, K., 2007a, 'Kan die Gereformeerde Kerke hoegenaamd nog met die evangelie uitreik?' Die Kerkblad, 39-41.

Van Rooy, K., 2007b, 'Sendingwerk in die toekoms ... Hoe en waarheen?' Die Kerkblad, April, 30-32.

Van Wyk, J.H., 2006, 'Waarom loop die kerke in Europa leeg? Die Kerkblad, November, $5-7$.

Venter, F., 2009, e-pos, 04 Maart, fanie@ksm.co.za

Vogel, W. (e.a.)., 2007, Almanak van die Gereformeede Kerke in Suid-Afrika, Jaargang 133, V \& R Drukkery (Edms.) Bpk., Pretoria.

Walls, A.F. 2002, The Cross-cultural process in Christian history - Studies in the Transmission and Appropriation of Faith, T \&T Clark, Edinburgh. 